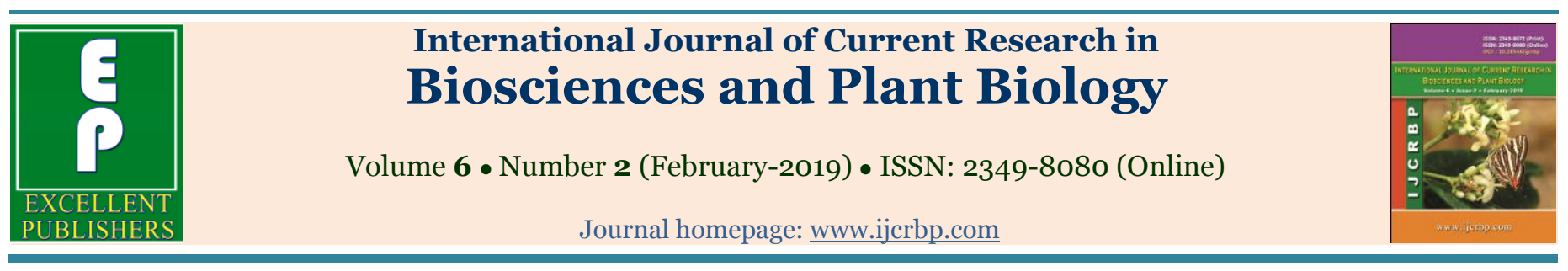

\title{
Phytochemical analysis and larvicidal potentials of Jatropha curcas L. leaf and stem extracts against Anopheles gambiae
}

\section{Peter Chikezie AYOGU ${ }^{1 *}$ and Celestina Chibuzo UGWU²}

1,2Lecturer, Department of Applied Microbiology and Brewing, Enugu State University of Science and Technology, Enugu, 400001, Nigeria

Postal Address: C/o Dr. Celestina C. Ugwu, Department of Applied Microbiology and Brewing, Enugu State University of Science and Technology, Enugu, Nigeria

*Corresponding author; e-mail: chikezieayogu@gmail.com; Phone: +234-7036325975.

\begin{tabular}{|c|c|}
\hline Article Info & ABSTRACT \\
\hline $\begin{array}{l}\text { Date of Acceptance: } \\
\text { 28 January } 2019 \\
\text { Date of Publication: } \\
\text { o6 February } 2019\end{array}$ & $\begin{array}{l}\text { This study determined the bio active substances in the physic nut plant, Jatropha } \\
\text { curcas and further examined the larvicidal potentials of its hexane, methanol and } \\
\text { aqueous leaf and stem extracts on locally reared larvae of the malaria vector, Anopheles } \\
\text { gambiae in accordance with the World Health Organization's guidelines for laboratory } \\
\text { and field testing of mosquito larvicides. Various concentrations }(25 \mathrm{mg} / \mathrm{mL}, 50 \mathrm{mg} / \mathrm{mL}\end{array}$ \\
\hline Keywords & larvae of Anopheles gambiae. Qualitative phytochemical analysis of the different \\
\hline $\begin{array}{l}\text { Anopheles gambiae } \\
\text { Jatropha curcas } \\
\text { Larval mortality } \\
\text { Larvicidal potentials } \\
\text { Lethal concentration } \\
\text { Phytochemical analysis }\end{array}$ & 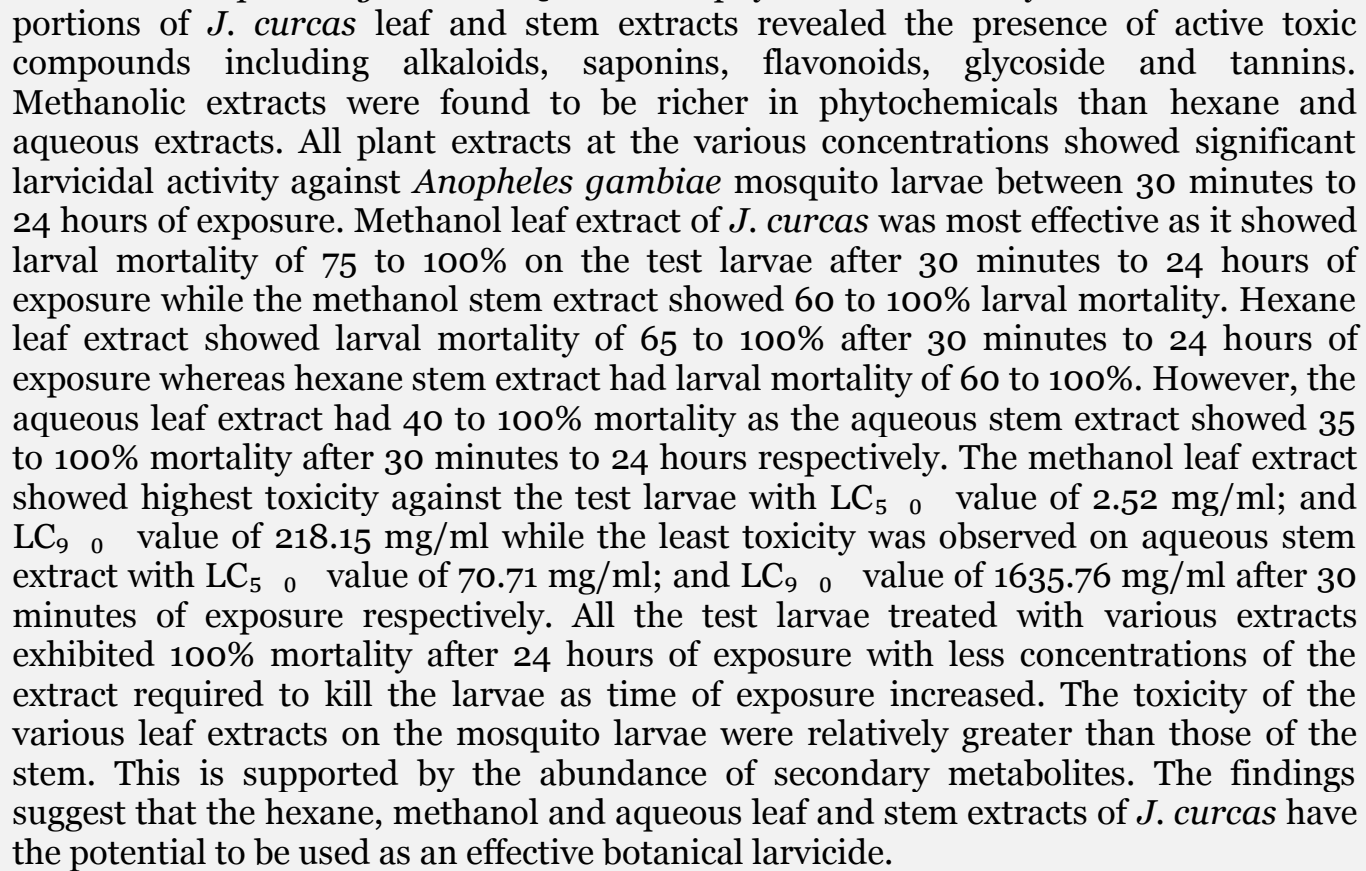 \\
\hline
\end{tabular}




\section{Introduction}

The search for an innovative vector control strategy involving the use of alternative insecticidal and larvicidal substances from plant materials has become of increasing importance in recent times due to the concerns over the environmental hazards associated with uncontrolled extensive use of synthetic larvicides and the development of resistance of the anopheline mosquitoes against synthetic larvicides. Many programs and researches are being embarked on to curb the high rate of malaria globally. Malaria is one of the most significant and debilitating insect-transmitted diseases which has infected humans for over thousand years and may have been a human pathogen for the entire history of mankind (Joy et al., 2003). The malaria disease in humans is characterized by symptom ranging from sudden fever and chills at regular intervals to fatigue, headache and sweating after each fever (Foster, and Walker, 2009).

According to a recent World Health Organization (WHO) report, 216 million cases of malaria occurred worldwide in 2016 and about 445,000 people died from the disease, mostly children under 5 years of age in sub-Saharan Africa (WHO, 2018). This represents at least one death (child) every 39 seconds and $85-90 \%$ of the deaths occur in subSaharan Africa (WHO, 2010). The mosquitoes have been identified as main malarial vectors. Efforts to reduce malaria cases need to be much directed at controlling proliferation of mosquitoes. Mosquito control methods include targeting the adult mosquito through spraying chemical insecticides or by killing the mosquito larvae before they emerge into adults via using synthetic larvicides or botanical extracts as an alternative larvicide (Tiwary et al., 2007). However, the emergence of insecticide resistant vectors (Jeffery, 1984) hampers the reduction of mosquito proliferation by the use of synthetic insecticides. Moreover, the use of indoor residual spraying method in the control of adult anopheline mosquitoes may become more successful and effective if mosquitoes are resting indoors prior to or after feeding on humans, the surfaces and the walls to be sprayed in human shelters are readily available, the interior of all houses are accessed and people are willing to accept that their homes be sprayed with the chemical insecticides (WHO, 2006).
Tomass et al. (2011) opined that malaria control programs can become more effective when the control measures are directed against the larval and other immature stages of mosquito vectors especially in areas where mosquito breeding sites are accessible and relatively in small populations (Tomass et al., 2011). Also in their work, Killeen et al. (2002) stated that because the immature stages of mosquitoes are usually confined within relatively small aquatic habitats, they cannot readily escape control measures. Thus it ishoped that great progress can be made in the control of malaria when the mosquitoes are at the developmental stages. Incidentally, with the application of synthetic larvicides such as malathion, methoprene, temephos, fenthion and chloropyrifos (Ali et al., 1995) the global malaria eradication campaign programs has not ended as some life stages of anopheline mosquitoes have been observed to develop different levels of physiological resistance against them (Vatandoost and Hanafi-Bojd, 2005). Furthermore, indiscriminate use of synthetic larvicidal chemicals are reported to result in environmental hazards (Nwani et al., 2013). It therefore becomes of great importance to identify alternative insecticidal/ larvicidal substances from plant materials which can be effective against different developmental stages of the mosquitoes while showing small or no harmful effect on non-target organisms and the environment (Chantraine et al., 1998; Cavalcanti et al., 2004).

Plants according to Prasad et al. (2012), are a rich source of many natural products most of which have been extensively used for human welfare, and treatment of various diseases. Jatropha curcas is a species of flowering, multipurpose, drought resistant, perennial plant belonging to Euphorbiaceae family. It is known for its several potentials in industrial application and medicinal values Martínez-Herrera et al. (2006). Many parts of the plant are used for the treatment of various diseases as they contain different amounts of many bio active substances which may act individually, additively or in synergy to improve health (Kumar and Sharma, 2006).

The latex contains alkaloids including jatrophine, jatropham and curcain which have anti-cancerous properties and serves as a disinfectant in mouth infections in children. It is also used externally 
against skin diseases, piles and sores among the domestic livestock (Thomas et al., 2011). Investigation show that the leaves contain the flavonoid-apigenin and glycosides-vitexin and isovitexin and sterols (Chhabra et al., 1990) which along with other factors enable them to be used against some ailments such as malaria, rheumatic and muscular pains (Thomas et al., 2008). Antibiotic activity of Jatropha has been observed against organisms including Staphylococcus aureus and Escherichia coli (Matsuse et al., 1998). The crude stem bark extracts of $J$. curcas were reported to inhibit the growth of pathogenic bacteria and fungi (Igbinosa et al., 2009). The plant is used as a natural pesticide because of its toxicity (Makkar et al., 1997). The seeds are also used as insecticides (Salimon and Abdullah, 2008). The seeds of Jatropha curcas when grounded with palm oil are used as rat poison. An aqueous extract of the leaves has insecticidal properties and the leaves are also used in fumigating houses against bed bug. The leaf extracts of Jatropha curcas has been attempted for larvicidal activity against Culex quinquefasciatus (Karmegam et al., 1997). The present study aims to evaluate the larvicidal potentials of several concentrations of the hexane, methanol and aqueous extracts of the leaves and stem of Jatropha curcas against third instar larvae of the malarial vector, Anopheles gambiae with a view to highlighting its efficacy; determine the bio active substances present in the plant as well as to discover the extract with the highest amount of these phytochemicals.

\section{Materials and methods}

All solvents and reagents used in our study are of the JDH grade and were sourced from Enugu, Nigeria.

\section{Collection of plant materials}

The leaf and stem samples of Jatropha curcas were harvested in May, 2018 from a local farm in Ugbene-Ajima, Uzo-Uwani L.G.A. of Enugu State, Nigeria. The plant was identified by the botanist in the department of Plant science and Biotechnology, University of Nigeria Nsukka, Nigeria; and specimen voucher deposited in same department. The leaf and stem samples were rinsed severally with clean water and the stem was sliced into pieces. The samples air-dried separately at ambient temperature for three weeks before they were grounded into powder with mortar and pestle. Each grounded sample was kept in an airtight container until required.

\section{Processing of the plant material}

One hundred and fifty grams (150) g of the powdered leaf material was macerated into a clean solvent bottle and 1.4 Litres of n-hexane was added, covered with a cork, mixed together properly and left on the shaker at $100 \mathrm{rpm}$ for 24 hours after which the extracts were filtered and squeezed through four layers of muslin cloth. Rotary evaporator was used to recover hexane from the extract for reuse. The plant material was recovered and subsequently remacerated using methanol and finally with distilled water. Same procedure was used to extract the bio active compounds in the stem sample. The filtrates obtained were stored separately and well labelled in sterile McCartney bottles and kept in the refrigerator at $4^{\circ} \mathrm{C}$ until used in mosquito larvicidal tests (Arekemase et al., 2011).

\section{Collection of mosquito larvae}

Mosquito larvae were gathered from the water present in the exposed water cans and broken pots in Opanda and Agbani, Enugu State, Nigeria. These were subsequently brought to laboratory where they were transferred to clean plastic containers with clear tap water. The larvae were covered with a mosquito net to ensure safety of workers in case of the fast emergence of the larvae into adult mosquitoes. They were kept at $27-28^{\circ} \mathrm{C}$. Third instar larvae were used for all the tests (WHO, 2005).

\section{Identification of mosquito larvae}

Larvae of a mosquito can be identified from any other aquatic insects by a combination of their two characters, they have no legs and the thorax is wider than the head or abdomen. The three divisions of the body part of mosquito larvae are head, thorax and abdomen. The structure of three body regions serves as the basis for identifying the mosquito larvae. The mosquito larva was identified using a compound microscope. The target mosquito larva in this study, the third instar larva of malaria mosquito was identified as follows: 
small amount of water with a mosquito larva was dropped onto a slide and specimen was viewed in the microscope (Gutierrez et al., 2014). Result was determined with the aid of WHO identification Manual.

Anopheles gambiae larvae which were used in this study can be distinguished from any other mosquito larvae since they normally lack the respiratory siphons used as breathing tubes in most other mosquito genera (Foster and Walker, 2009). Larvae are very small in the first instar and increase in size until reaching 5 to $6 \mathrm{~mm}$ by the completion of the fourth instar.

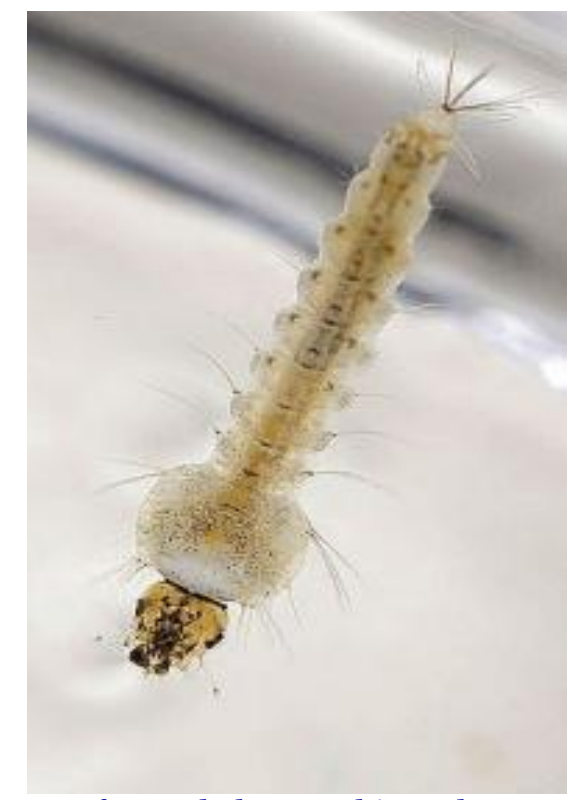

Fig. 1: Larva of Anopheles gambiae. Photograph by Ray Wilson, Bird and Wildlife Photography, 2014.

\section{Preparation of the test and control solutions}

The various portions of the extracts of both the leaves and stem of $J$. curcas were not readily soluble in water. Two grams (2) g of each of the leaf extracts were dissolved in 10ml of dimethyl sulfoxide (DMSO) to prepare stock solutions and the bottles were tightly covered and agitated to enhance dissolution. The mixtures were serially diluted to $10 \mathrm{ml}$ using sterile distilled water to prepare diluted test concentrations including 200, 100, 50 and $25 \mathrm{mg} / \mathrm{mL}$ in accordance with Sakthivadivel and Daniel (2008). Serially diluted test concentrations of the stem extracts were also prepared as above27. An equal volume of water containing 2 drops of the dimethyl sulfoxide (DMSO) was used as control for the larvicidal bioassay since it was not toxic to the test larvae.

\section{Mosquito larvicidal bioassay}

The larvicidal bioassays were conducted in accordance with World Health Organization's guidelines for laboratory and field testing of mosquito larvicides (WHO, 2005). Using batches of 10 third instar larvae of Anopheles gambiae, bioassays were done for 24 hours in glass Petri dishes of $10 \mathrm{ml}$ test solutions with 2 replicates of each test concentration for the n-hexane, methanol and aqueous leaf extracts of $J$. curcas and those of hexane, methanol and aqueous stem extracts. The larvae were transferred into each test concentrations of the extracts by means of droppers and needles and larval mortalities were recorded with the $200 \mathrm{mg} / \mathrm{ml}, 100 \mathrm{mg} / \mathrm{ml}$, $50 \mathrm{mg} / \mathrm{ml}$ and $25 \mathrm{mg} / \mathrm{ml}$ concentrations of the various test solutions after 30 minutes, 60 minutes, 6 hours, 12 hours and 24 hours of exposure (Gutierrez et al., 2014). All the larvae that failed to move after probing them with a needle at their cervical region. Moribund larvae were those incapable of rising to the surface or moving within a reasonable period of time when the test solutions were disturbed were confirmed dead. Moribund larvae were counted and added to dead larvae (WHO, 2005). The percentage mortality was calculated using the relation below (Vinchurkar et al., 2017).

Percentage mortality $=\frac{\text { Number of dead larvae }}{\text { Number of larvae introduced }} \times 100$

\section{Phytochemical analysis}

Phytochemical examinations were carried out for all the extracts as per the standard methods as described by Tiwari et al. (2011). The Wagner's test was used to test for alkaloids; froth test for saponins; alkaline reagent test for flavonoids; Libermann Burchard's test for steroids; gelatin test for tannins; Legal's test for glycosides and copper acetate test for terpenoids (Tiwari et al., 2011).

\section{Test for alkaloids}

Extracts were dissolved individually in dilute Hydrochloric acid and filtered. 
Wagner's Test: Filtrates were treated with Wagner's reagent (Iodine in Potassium Iodide). Formation of brown/reddish precipitate indicated the presence of alkaloids.

\section{Test for saponins}

Froth Test: Extracts were diluted with distilled water to $20 \mathrm{ml}$ and this was shaken in a graduated cylinder for 15 minutes. Formation of layer of foam indicated the presence of saponins.

\section{Test for flavonoids}

Alkaline reagent test: Extracts were treated with few drops of sodium hydroxide solution. Formation of intense yellow colour which becomes colourless on addition of dilute acid, indicated the presence of flavonoids.

\section{Test for steroids}

Libermann Burchard's test: Extracts were treated with chloroform and filtered. The filtrates were treated with few drops of acetic anhydride, boiled and cooled. Concentrated sulphuric acid was added. Formation of brown ring at the junction indicated the presence of steroids.

\section{Test for tannins}

Gelatin Test: 1\% gelatin solution containing sodium chloride was added to the extract. Formation of white precipitate indicated the presence of tannins.

\section{Test for glycosides}

Legal's test: Extracts were treated with sodium nitropruside in pyridine and sodium hydroxide. Formation of pink to blood-red colour indicated the presence of cardiac glycosides.

\section{Test for diterpenes}

Copper acetate test: Extracts were dissolved in water and treated with 3-4 drops of copper acetate solution. Formation of emerald-green colour indicated the presence of diterpenes (Tiwari et al., 2011).

\section{Results}

\section{Larvicidal activity of leaf and stem extracts of Jatropha curcas}

The percentage mortalities and mean percentage mortalities of the larvae of Anopheles gambiae to the various concentrations of leaf and stem extracts of $J$. curcas were determined by one-way analysis of variance (ANOVA) using SPSS for windows, version 22 after 24 hours of exposure. ANOVA was also used to test variation in larval mortalities among n-hexane, methanol and aqueous leaf and stem extracts at the test concentrations. The $\mathrm{LC}_{5} \quad 0 \quad$ and the $\mathrm{LC}_{9} \quad{ }_{0} \quad$ values for the leaf and stem extract test solutions of $J$. curcas were determined using dosage mortality probit regression analyses of SPSS program version 22 to determine their larvicidal efficacies (WHO, 2005). The results are presented in the tables below.

Table 1. Mean \% larval mortalities of the methanol leaf extract.

\begin{tabular}{|c|c|c|c|c|c|}
\hline \multirow{2}{*}{$\begin{array}{l}\text { Methanol Leaf } \\
\text { Extract }\end{array}$} & \multicolumn{5}{|c|}{ Mean \% mortality after } \\
\hline & $30 \mathrm{mins}$ & $60 \mathrm{mins}$ & $6 \mathrm{hrs}$ & 12 hrs & 24 hrs \\
\hline Control & 0 & $\mathrm{O}$ & 0 & 0 & 0 \\
\hline $25 \mathrm{mg} / \mathrm{ml}$ & 75 & 85 & 90 & 90 & 100 \\
\hline $50 \mathrm{mg} / \mathrm{ml}$ & 80 & 90 & 85 & 95 & 100 \\
\hline $100 \mathrm{mg} / \mathrm{ml}$ & 90 & 95 & 90 & 95 & 100 \\
\hline $200 \mathrm{mg} / \mathrm{ml}$ & 90 & 95 & 95 & 100 & 100 \\
\hline
\end{tabular}

Table 2. Mean \% larval mortalities of the hexane leaf extract.

\begin{tabular}{llllll}
\hline Hexane Leaf & \multicolumn{2}{l}{ Mean \% mortality after } & & \\
\cline { 2 - 6 } Extract & $\mathbf{3 0}$ mins & 60 mins & $\mathbf{6 ~ h r s}$ & $\mathbf{1 2}$ hrs & $\mathbf{2 4}$ hrs \\
\hline Control & 0 & 0 & 0 & 0 & 0 \\
$25 \mathrm{mg} / \mathrm{ml}$ & 65 & 70 & 85 & 85 & 100 \\
$50 \mathrm{mg} / \mathrm{ml}$ & 70 & 75 & 90 & 95 & 100 \\
$100 \mathrm{mg} / \mathrm{ml}$ & 75 & 80 & 95 & 95 & 100 \\
$200 \mathrm{mg} / \mathrm{ml}$ & 80 & 90 & 95 & 100 & 100 \\
\hline
\end{tabular}

P. C. Ayogu and C. C. Ugwu (2019) / Phytochemical analysis and larvicidal potentials of Jatropha curcas L. leaf and stem 
Table 3. Mean \% larval mortalities of the aqueous leaf extract.

\begin{tabular}{|c|c|c|c|c|c|}
\hline \multirow{2}{*}{$\begin{array}{l}\text { Aqueous Leaf } \\
\text { Extract }\end{array}$} & \multicolumn{5}{|c|}{ Mean \% mortality after } \\
\hline & $30 \mathrm{mins}$ & $60 \mathrm{mins}$ & $6 \mathrm{hrs}$ & 12 hrs & 24 hrs \\
\hline Control & 0 & 0 & 0 & $\mathrm{O}$ & $\mathrm{O}$ \\
\hline $25 \mathrm{mg} / \mathrm{ml}$ & 40 & 60 & 75 & 85 & 100 \\
\hline $50 \mathrm{mg} / \mathrm{ml}$ & 50 & 75 & 85 & 90 & 100 \\
\hline $100 \mathrm{mg} / \mathrm{ml}$ & 60 & 80 & 90 & 90 & 100 \\
\hline 200mg/ml & 75 & 85 & 95 & 100 & 100 \\
\hline
\end{tabular}

Table 4. Mean \% larval mortalities of the methanol stem extract.

\begin{tabular}{|c|c|c|c|c|c|}
\hline \multirow{2}{*}{$\begin{array}{l}\text { Methanol stem } \\
\text { extract }\end{array}$} & \multicolumn{5}{|c|}{ Mean \% mortality after } \\
\hline & $30 \mathrm{mins}$ & $60 \mathrm{mins}$ & $6 \mathrm{hrs}$ & 12 hrs & $24 \mathrm{hrs}$ \\
\hline Control & 0 & 0 & 0 & 0 & 0 \\
\hline $25 \mathrm{mg} / \mathrm{ml}$ & 60 & 75 & 90 & 95 & 100 \\
\hline $50 \mathrm{mg} / \mathrm{ml}$ & 70 & 80 & 95 & 100 & 100 \\
\hline $100 \mathrm{mg} / \mathrm{ml}$ & 75 & 85 & 90 & 100 & 100 \\
\hline $200 \mathrm{mg} / \mathrm{ml}$ & 85 & 90 & 100 & 100 & 100 \\
\hline
\end{tabular}

Table 5. Mean \% larval mortalities of the hexane stem extract.

\begin{tabular}{llllll}
\hline Hexane stem & \multicolumn{2}{l}{ Mean \% mortality after } & & \\
\cline { 2 - 6 } extract & 30 mins & 6o mins & 6 hrs & 12 hrs & 24 hrs \\
\hline Control & 0 & 0 & 0 & 0 & 0 \\
$25 \mathrm{mg} / \mathrm{ml}$ & 60 & 65 & 75 & 90 & 100 \\
$50 \mathrm{mg} / \mathrm{ml}$ & 60 & 75 & 90 & 90 & 100 \\
$100 \mathrm{mg} / \mathrm{ml}$ & 80 & 85 & 90 & 95 & 100 \\
$200 \mathrm{mg} / \mathrm{ml}$ & 85 & 85 & 95 & 100 & 100 \\
\hline
\end{tabular}

Table 6. Mean \% larval mortalities of the aqueous stem extract.

\begin{tabular}{|c|c|c|c|c|c|}
\hline \multirow{2}{*}{$\begin{array}{l}\text { Aqueous stem } \\
\text { extract }\end{array}$} & \multicolumn{5}{|c|}{ Mean \% mortality after } \\
\hline & 30 mins & $60 \mathrm{mins}$ & $6 \mathrm{hrs}$ & 12 hrs & $24 \mathrm{hrs}$ \\
\hline Control & $\mathrm{O}$ & $\mathrm{O}$ & 0 & $\mathrm{o}$ & 0 \\
\hline $25 \mathrm{mg} / \mathrm{ml}$ & 35 & 50 & 65 & 75 & 100 \\
\hline $50 \mathrm{mg} / \mathrm{ml}$ & 40 & 50 & 70 & 80 & 100 \\
\hline $100 \mathrm{mg} / \mathrm{ml}$ & 60 & 70 & 85 & 90 & 100 \\
\hline $200 \mathrm{mg} / \mathrm{ml}$ & 65 & 80 & 90 & 95 & 100 \\
\hline
\end{tabular}

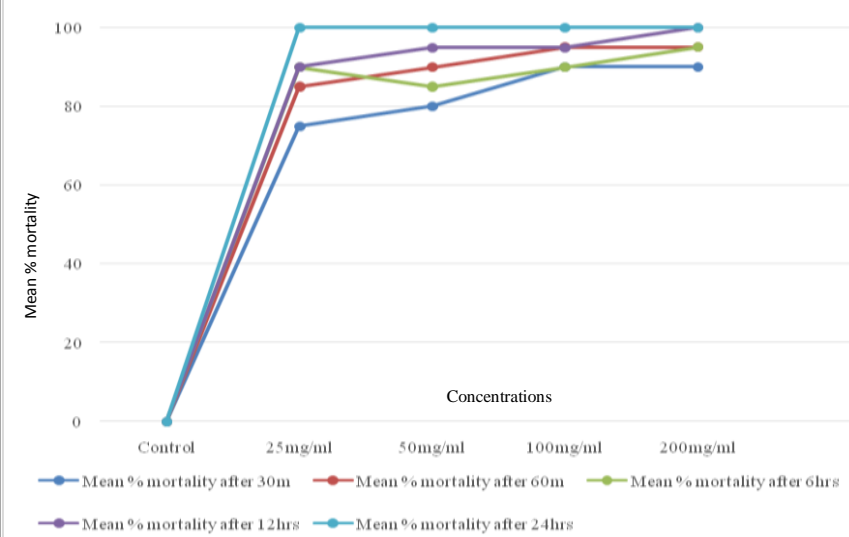

Fig. 2: Mean \% larval mortalities induced by the various concentrations of the methanol leaf extract of Jatropha curcas on the third instar larvae of Anopheles gambiae after 24 hours of exposure.

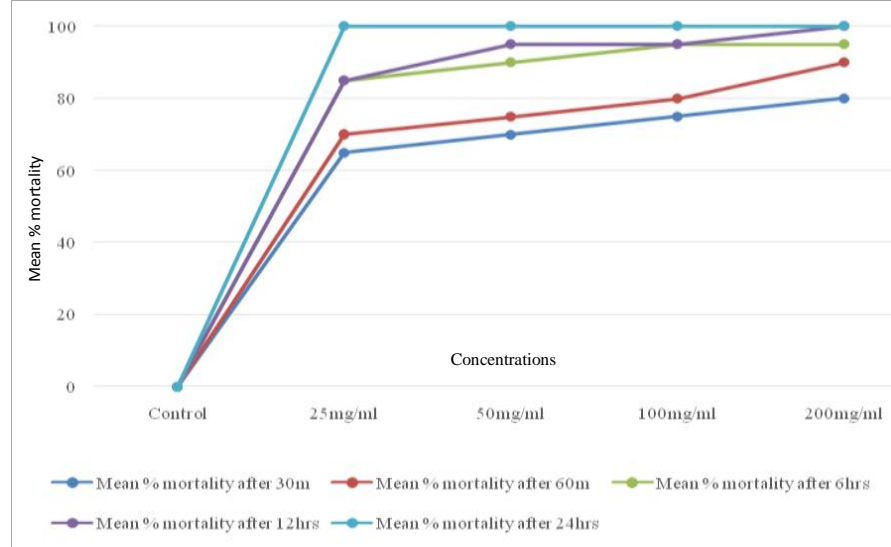

Fig. 3: Mean \% larval mortalities induced by the various concentrations of the hexane leaf extract of Jatropha curcas on the third instar larvae of Anopheles gambiae after 24 hours of exposure. 


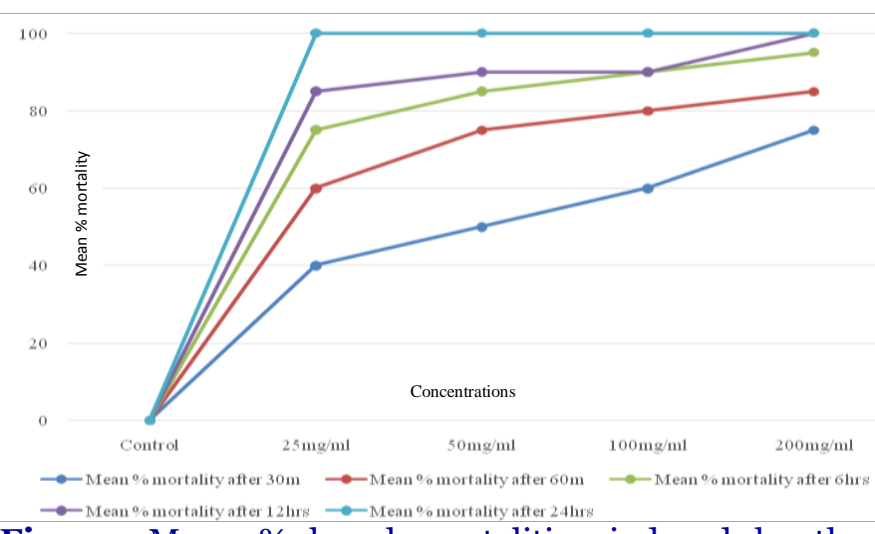

Fig. 4: Mean \% larval mortalities induced by the various concentrations of the aqueous leaf extract of Jatropha curcas on the third instar larvae of Anopheles gambiae after 24 hours of exposure.

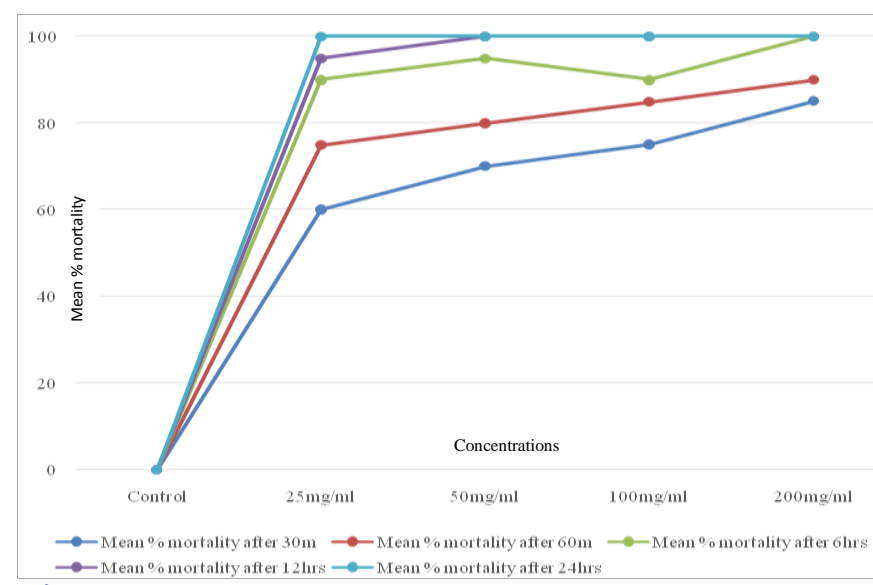

Fig. 5: Mean \% larval mortalities induced by the various concentrations of the methanol stem extract of Jatropha curcas on the third instar larvae of Anopheles gambiae after 24 hours of exposure.

\section{Phytochemical analysis}

From this study, the qualitative phytochemical screening of Jatropha curcas leaf extracts revealed the presence of flavonoids, steroids, glycosides, saponins, alkaloids and terpenoids (Table 7), whereas the stem extracts were observed to contain relatively smaller amounts of saponins, tannins, alkaloids, flavonoids, steroids and glycosides (Table 8). However, the leaves of $J$. curcas contain

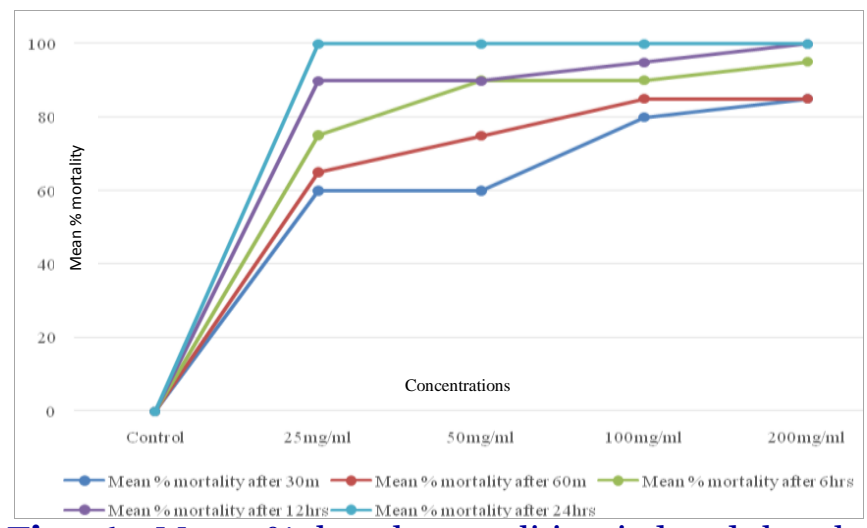

Fig. 6: Mean \% larval mortalities induced by the various concentrations of the hexane stem extract of Jatropha curcas on the third instar larvae of Anopheles gambiae after 24 hours of exposure.

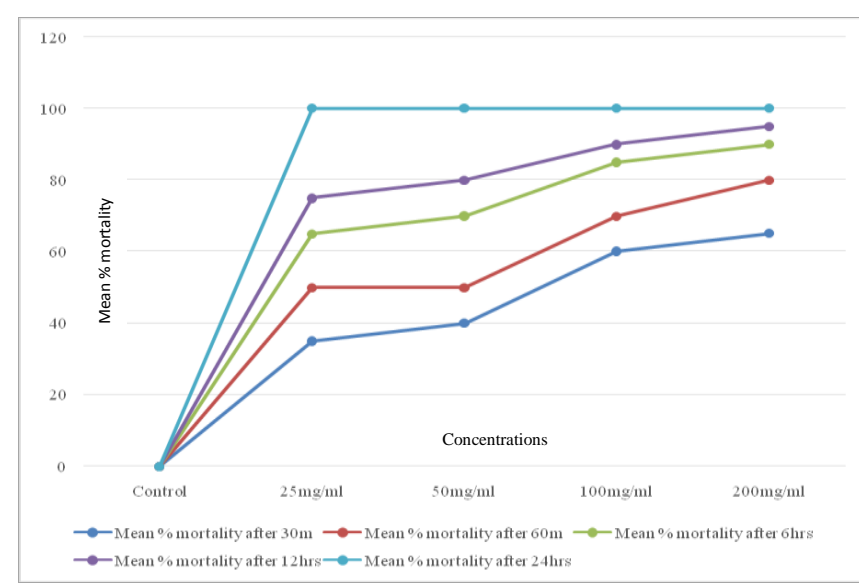

Fig. 7: Mean \% larval mortalities induced by the various concentrations of the aqueous stem extract of Jatropha curcas on the third instar larvae of Anopheles gambiae after 24 hours of exposure.

more steroids than those of the stem. The phytochemicals of the plants serve as huge storage of compounds that have biological action (Vatandoost and Hanafi-Bojd, 2005). Alkaloids, saponins, and tannins are known to possess medicinal and pesticidal properties (Azmathullah et al., 2011). Saponins are known by their toxicity to harmful insects ${ }^{32}$.Thelethalconcentrations $\left(\begin{array}{lll}\mathrm{LC}_{5} & 0 & \text { and } \\ \mathrm{LC}_{9} & 0\end{array}\right)$ values for the extracts are summarized in Table 9.

Table 7. Phytochemicals present in the leaf extracts of Jatropha curcas plant.

\begin{tabular}{llllllll}
\hline Extracts & Alkaloids & Saponins & Flavonoids & Steroids & Tannins & Glycosides & Terpenoids \\
\hline n-Hexane & ++ & - & + & ++ & - & + & + \\
Methanol & +++ & ++ & + & +++ & - & + & - \\
Aqueous & ++ & ++ & - & + & - & - & - \\
\hline
\end{tabular}

P. C. Ayogu and C. C. Ugwu (2019) / Phytochemical analysis and larvicidal potentials of Jatropha curcas L. leaf and stem extracts against Anopheles gambiae 
Table 8. Phytochemicals present in the stem extracts of Jatropha curcas plant.

\begin{tabular}{llllllll}
\hline Extracts & Alkaloids & Saponins & Flavonoids & Steroids & Tannins & Glycosides & Terpenoids \\
\hline n-Hexane & + & - & + & + & + & - & + \\
Methanol & +++ & + & + & ++ & ++ & + & - \\
Aqueous & ++ & + & - & + & + & - & - \\
\hline Key: + = Slightly positive; ++ & r Positive; - = Negative. & &
\end{tabular}

Determination of $\mathrm{LC}_{5} \quad 0$ and $\mathrm{LC}_{9} \quad 0 \quad$ values

Table 9. Lethal Concentrations $\left(\begin{array}{llll}\mathrm{LC}_{5} & 0 & \text { andLC } & 0\end{array}\right)$ values $(\mathrm{mg} / \mathrm{ml})$ of the leaf and stem extracts of Jatropha curcas on the third instar larvae of Anopheles gambiae after 24 hours of exposure. Key: NA= Not Applicable.

\begin{tabular}{|c|c|c|c|c|c|c|c|c|c|c|}
\hline \multirow{3}{*}{ Extracts } & \multicolumn{10}{|l|}{ Time } \\
\hline & \multicolumn{2}{|c|}{$30 \mathrm{mins}$} & \multicolumn{2}{|c|}{$60 \mathrm{mins}$} & \multicolumn{2}{|c|}{6 hours } & \multicolumn{2}{|c|}{12 hours } & \multicolumn{2}{|c|}{24 hours } \\
\hline & $\mathbf{L C}_{5} 0$ & $L_{\mathbf{9}_{0}}$ & $\mathbf{L C}_{5} 0$ & $L_{9_{0}}$ & $\mathbf{L C}_{5} 0$ & $L_{C_{9}} 0$ & $L_{C_{5}} 0$ & $L_{9_{0}}$ & $\mathbf{L C}_{5} 0$ & $\mathrm{LC}_{9}$ \\
\hline Methanol leaf & 2.52 & 218.15 & 0.99 & 49.31 & 0.04 & 66.17 & 0.038 & 54.12 & NA & NA \\
\hline $\begin{array}{l}\text { Methanol } \\
\text { stem }\end{array}$ & 12.39 & 451.76 & 2.52 & 218.15 & 0.50 & 27.74 & 0.47 & $25 \cdot 73$ & NA & NA \\
\hline Hexane leaf & 4.41 & $155^{2.53}$ & 6.07 & 275.00 & 0.99 & 49.31 & 0.84 & 40.21 & NA & NA \\
\hline Hexane stem & 17.25 & 367.59 & 7.22 & 304.01 & 4.52 & 81.78 & 3.27 & 70.43 & NA & NA \\
\hline Aqueous leaf & 48.20 & 915.80 & 10.69 & 336.09 & $5 \cdot 54$ & 92.57 & 3.91 & 81.45 & NA & NA \\
\hline Aqueous stem & 70.71 & 1635.76 & 32.49 & 620.78 & 12.19 & 201.37 & 9.42 & 189.40 & NA & NA \\
\hline
\end{tabular}

\section{Discussion}

Most parts of the physic nut plant, Jatropha curcas are reportedly found to be toxic to the mosquito larvae (Kumar and Sharma, 2008), probably due to their contents of the bioactive compounds. This goes to explain the larvicidal activity shown in the present study. In the hexane leaf extract, alkaloids, flavonoids, steroids, glycosides and terpenoids were present while alkaloids, flavonoids, steroids and terpenoids were found in the hexane stem extract. Alkaloids, saponins, flavonoids, steroids and glycosides were present in the methanol leaf and stem extracts. However, tannins were present only in the methanol stem extract while terpenoids were absent in both. The aqueous leaf extract was found to contain alkaloids, saponins and steroids while the aqueous stem extract contains tannins, saponins, steroids and alkaloids all of which were relatively lesser in the aqueous stem extract. This agrees with the findings of Igbinosa et al. (2009) who conducted phytochemical screening and antimicrobial activity of stem bark extracts from Jatropha curcas to reveal the presence of saponins, steroids, tannins, glycosides, alkaloids and flavonoids ${ }^{21}$. The finding also seemed to be related to the report of Gutierrez et al. (2014) who reported the presence of alkaloids, flavonoids and steroids in both leaf and stem/bark extracts of $J$. curcas with less amount of flavonoids in the methanol leaf extract. In their work, they concluded that the presence of several bioactive chemicals like alkaloids, saponins, tannins, flavonoids and steroids can be attributed to the susceptibility of the plant extracts as killing agent against mosquito larvae. The phytochemicals of the plants serve as huge storage of compounds that have biological action (Howard et al., 2007). Alkaloids, saponins, and tannins are known to possess medicinal and pesticidal properties (Azmathullah et al., 2011), while saponins are known by their toxicity to harmful insects (Chaieb, 2010). All plant extracts showed significant larvicidal activity against Anopheles gambiae mosquito larvae at 0.05 level of significance. After 30 minutes of exposure, the mosquito larvae exhibited appreciable rate of mortality to most of the extracts. Methanol leaf extract of Jatropha curcas was the most effective larvicide as it showed larval mortality of 75 to $100 \%$ on the test larvae after 30 minutes to 24 hours of exposure while the methanol stem extract showed larval mortality of 60 to $100 \%$ on the test larvae. Hexane leaf extract showed larval mortality of 65 to $100 \%$ after 30 minutes to 24 hours of exposure whereas hexane stem extract had larval mortality of 60 to $100 \%$. However, larval mortality of the aqueous leaf extract (40 to 100\%) and aqueous stem extract (35 to $100 \%$ ) decreased appreciably. The methanol leaf extract showed highest toxicity against the test larvae with $\mathrm{LC}_{5} 0_{0}$ value of $2.52 \mathrm{mg} / \mathrm{ml}$; and 
$\mathrm{LC}_{9} \quad 0 \quad$ value of $218.15 \mathrm{mg} / \mathrm{ml}$ after 30 minutes and $\mathrm{LC}_{5}{ }_{0}$ value of $0.038 \mathrm{mg} / \mathrm{ml}$; and $\mathrm{LC}_{9}{ }_{0}$ value of $54.12 \mathrm{mg} / \mathrm{ml}$ after 12 hours of exposure while the least toxicity was observed on aqueous stem extract with $\mathrm{LC}_{5}{ }_{0}$ value of $70.71 \mathrm{mg} / \mathrm{ml}$; and $\mathrm{LC}_{9}{ }_{0}$ value of $1635.76 \mathrm{mg} / \mathrm{ml}$ after 30 minutes and $\mathrm{LC}_{5}{ }_{0}$ value of $9.42 \mathrm{mg} / \mathrm{ml}$; and $\mathrm{LC}_{9} \quad 0 \quad$ value of $189.40 \mathrm{mg} / \mathrm{ml}$ after 12 hours of exposure. This finding is however not directly in agreement with Tomass et al. (2011). In their study, Tomass et al. (2011) evaluated the larvicidal effects of Jatropha curcas against Anopheles arabiensis and had reported that crude methanolic extract of $J$. curcas showed higher larval mortality against third instar larvae of Anopheles arabiensis than that of its column chromatographic fractions (Fatnassi et al., 2014). All the test larvae treated with various extracts died after 24 hours of exposure with less concentrations of the extract required to kill the larvae as time of exposure increased. The finding seemed to correlate with the report of Fatnassi et al. (2014) who evaluated the larvicidal efficacy of Jatropha curcas leaf and seed aqueous extracts against Culex pipiens and reported $100 \%$ and between 60 to $100 \%$ mortality for aqueous seed extract and aqueous leaf extract after 24 hours of exposure respectively (Tomass et al., 2011). Kaushiki and Mahesh (2013) who had evaluated the phytochemicals and larvicidal activity of Jatropha curcas seed oil against Aedes aegypti reported that the hexane extract of $J$. curcas seed oil had highest mortality against the fourth-instar larvae of Aedes aegypti with values $\mathrm{LC}_{5} 0_{0}=640 \mathrm{ppm}$ (0.064\%) after 24 hours of exposure (Kaushiki and Mahesh, 2013). Their report suggested that the seed oil extract of J.curcas can be effectively used as potential candidates for controlling Aedesaegypti and can be considered for eco-friendly vector control programs (Kaushiki and Mahesh, 2013). A study carried out by Vinchurkar et al. (2017) also showed that acetone, methanol and aqueous leaf extracts of Jatropha curcas can be used effectively against Aedes aegypti and can be considered an ecofriendly larvicide against mosquitoes (Vinchurkar et al., 2017).

\section{Conclusion}

This study revealed the phytochemicals and determined the larvicidal potentials of the hexane, methanol and aqueous leaf extract of $J$. curcas and those of its stem extracts against the third instar larvae of Anopheles gambiae, the major vector of malaria in Nigeria and many parts of Africa. The findings showed that the hexane and methanol extracts of both the leaves and stem of $J$. curcas showed more significant larvicidal activities on the third instar larvae of Anopheles gambiae than the aqueous extracts. However, the methanol leaf and stem extracts tend to be more efficient larvicides as they both contain more of the bioactive compounds. This study has shown that there is larvicidal potential in the physic nut plant at such concentrations of the various portions of its leaf and stem extracts. There is therefore the need to further exploit the physic nut plant in order to maximize its potential. Also, studies need to be embarked on to determine the larvicidal activities of different extracts of $J$. curcas against other malaria vectors especially in Nigeria. Subsequently, determination of the residual activities of the hexane, methanol and aqueous leaf and stem extracts of $J$. curcas and its effects on non-target organisms is highly recommended. Finally, the evaluation of the toxic activities of the various parts of $J$. curcas is important as to ascertain their safety on humans.

\section{Conflict of interest statement}

Authors declare that they have no conflict of interest.

\section{References}

Ali, A., Nayar, J.K., Xue, D., 1995. Comparative toxicity of selected larvicides and insect growth regulators to a Florida laboratory population of Aedes albopictus. J. Amer. Mosquito Control Assoc. 11(1), 72-76.

Arekemase, M. O., Kayode, R. M. O., Ajiboye, A. E., 2011. Antimicrobial activity and phytochemical analysis of Jatropha curcas plant against some selected microorganisms. Int. J. Biol. 3(3), 5257.

Azmathullah, N. M. D., Asrar Sheriff, M., Sultan Mohideen, A. K., 2011. Phytochemical screening of Calotropis procera flower extracts and their bio-control potential on Culex sp. mosquito larvae and pupae. Int. J. Pharmaceut. Biol. Arch. 2(6), 1718-1721.

Cavalcanti, E.S.B.C., Morais, S.M., Lima, M.A.A., 
Santana, E.W.P., 2004. Larvicidal activity of the essential oil from Brazilian plants against Aedes aegypti. Mem. Inst. Oswaldo Cruz. 99, 541-544.

Chaieb, I., 2010. Saponins as insecticides: A Review. Tun. J. Plant Prot. 5, 39-50.

Chantraine, J.M., Laurent, D., Ballivian, C., Saavedra, G., Ibanez, R., Vilaseca, L.A., 1998. Insecticidal activity of essential oils on Aedes aegypti larvae. Phytother. Res. 12, 350-354.

Chhabra, S.C., Mahunnah, R.L.A., Mshiu, E.N., 1990. Plants used in traditional medicine in Eastern Tanzania. III Angiosperms (Euophorbiaceae to Menispermaceae). J. Ethnopharmacol. 28, 255.

Fatnassi, B., Khouja, M. L., El Ferchichi Ouarda, H., 2014. Larvicidal efficacy of Jatropha curcas L. (Euphorbiaceae) leaf and seed aqueous extracts against Culex pipiens L. Afr. J. Biotechnol. 13 (26), 2641-2647.

Foster, W.A., Walker, E.D., 2009. Mosquitoes (Culicidae). In: Mullen, G., Durden, L. (Eds.) Medical and Veterinary Entomology. 2nd Edn. Academic Press, Burlington, MA. 637 p.

Gutierrez, P. M., Antepuesto, A. N., Bryle-Adrian, L. Eugenio, B. A. L., Santos, M. F. L., 2014. Larvicidal activity of selected plant extracts against the dengue vector Aedes aegypti mosquito. Int. Res. J. Biol. Sci. 3(4), 23-32.

Howard, A. F. B., Zhou, G., Omlin, F. X., 2007. Malaria mosquito control using edible fish in western Kenya: preliminary findings of a controlled study, BMC. Public Health. 7, 199204.

Igbinosa, O. O., Igbinosa, E. O., Aiyegoro, O. A. 2009.Antimicrobial activity and phytochemical screening of stem bark extracts from Jatropha curcas (Linn). Afr. J. Pharmacol. 3, 58-62.

Jeffery, G. M., 1984. The role of chemotherapy in malaria control through primary health care: Constraints and future prospects. Bull. World Health Organiz. 62, 49-53.

Joy, D. H., Feng, X., Mu, J., 2003. Early origin and recent expansion of Plasmodium falciparum. Science. 300(5617), 318-321.

Karmegam, N., Sakthivadivel, M., Anuradha, V., Daniel, T., 1997. Indigenous-plant extracts as larvicidal agents against Culex quinquefasciatus Say. Bioresour. Technol. 59, 137-140.

Kaushiki, O., Mahesh, P., 2013. Evaluation of phytochemicals, larvicidal activity of Jatropha curcas seed oil against Aedes aegypti. Int. J.
Appl. Res. Stud. 2(12), 1-12.

Killeen, G. F., Fillinger, U., Knols, B. G. J., 2002. Advantages of larval control for African malaria vectors: low mobility and behavioural responsiveness of immature mosquito stages allow high effective coverage. Malaria J. 1, 1-7.

Kumar, A., Sharma, S., 2008. An evaluation of multipurpose oil seed crop for industrial uses Jatropha curcas L.: A review. Ind. Crops Prod. 10, 101.

Makkar, H. P. S., Becker, K., Sporer, F., Wink, M., 1997. Studies on nutritive potential and toxic constituents of different provenances of Jatropha curcas. J. Agric. Food Chem. 45, 3152-3157.

Martínez-Herrera, J., Siddhuraju, P., Francis, G., Davila-Ortíz, G., Becker, K., 2006. Chemical composition, toxic/antimetabolic constituents, and effects of different treatments on their levels, in four provenances of Jatropha curcas L. from Mexico. Food Chem. 96, 80-89.

Matsuse, I. T., Lim, Y. A., Hattori, M., Correa, M., Gupta, M. P., 1998. A search for anti-viral properties in Panamanian medicinal plants: the effects on HIV and its essential enzymes. J. Ethnopharmacol. 64, 15-22.

Nwani, C. D., Ugwu, D.O., Okeke, O.C., Onyishi, G.C., Ekeh, F.N., Atama, C., Eneje, L.O., 2013. Toxicity of the chlorpyrifos-based pesticide Termifosß: effects on behaviour and biochemical and haematological parameters of African catfish Clarias gariepinus. Afr. J. Aquatic Sci. 38, 255-262.

Prasad, D. M. R., Izam, A., Khan, M. R., 2012. Jatropha curcas: Plant of medicinal benefits. J. Med. Plants Res. 6(14), 2691-2699.

Sakthivadivel, M., Daniel, T., 2008. Evaluation of certain insecticidal plants for the control of vector mosquitoes vis. Culex quinquefaciatus, Anopheles staphensi and Aedes aegypti. Appl. Entomol. Zool. 43, 57-63.

Salimon, J., Abdullah, R., 2008. Physicochemical properties of Malaysian Jatropha curcas seed oil. Sains Malays. 37, 379-382.

Thomas, R., Sah, N. K., Sharma, P. B., 2008. Therapeutic biology of Jatropha curcas: A mini review. Curr. Pharmaceut. Biotechnol. 9, 315324.

Tiwari, P., Kumar, B., Kaur, M., Kaur, G., Kaur, H., 2011. Phytochemical screening and extraction: A review. Int. Pharmaceut. Scien. 1(1), 98-106.

Tiwary, M., Naik, S. N., Tewary, D. K., Mittal, P. K., 
Yadav, S., 2007. Chemical composition and larvicidal activities of the essential oil of Zanthoxylum armatum DC (Rutaceae) against three mosquito vectors. J. Vector Borne Dis. 44, 198-204.

Tomass, Z., Hadis, M., Taye, A., Mekonnen, Y., Petros, B., 2011. Larvicidal effects of Jatropha curcas L. against Anopheles arabiensis (Diptera: Culicidea). Momona Eth. J. Sci. 3 (1), 52-64.

Vatandoost, H., Hanafi-Bojd, A. A., 2005. Current resistance status of Anopheles stephensi Liston to different larvicides in Hormozgan Province, southeastern Iran, 2004. Pak. J. Biol. Sci. 8(11), 1568- 1570.

Vinchurkar, A. S., Dama, L. B., Kulkarni, P. S., 2017. Screening for larvicidal activity of Jatropha curcas plant extracts against Aedes aegypti. Open Access Int. J. Sci. Eng. 2(12),
14-16.

World Health Organization, 2005. Guidelines for Laboratory and Field Testing of Mosquito Larvicides, http://whqlibdoc.who.int/hq. (21/ 02/2018).

World Health Organization, 2006. Malaria Vector Control and Personal Protection. A report of a WHO study group. 936th technical report series.

World Health Organization, 2010. World Malaria Report, World Health Organization, Geneva, Switzerland. http://www.who.int/malaria/ world_malaria_report_2010/malaria2010 _summary_keypoints_en.pdf(21/02/2018)

World Health Organization, 2018. Malaria Worldwide Information for Travelers. https://www.who.int/malaria/travellers/en/ (12/06/2018).

\section{How to cite this article:}

Ayogu, P. C., Ugwu, C. C., 2019. Phytochemical analysis and larvicidal potentials of Jatropha curcas L. leaf and stem extracts against Anopheles gambiae. Int. J. Curr. Res. Biosci. Plant Biol. 6(2), 48-60.

doi: https://doi.org/10.20546/ijcrbp.2019.602.004 


\section{Annexure - I. Supplementary tables}

Supplementary Table 1. Mortalities of Anopheles gambiae larvae treated with $200 \mathrm{mg} / \mathrm{mL}$ of extracts.

\begin{tabular}{llllll}
\hline \multicolumn{2}{l}{ Mortality in time } & & & 200 mg/ml \\
\hline Time & After 30 mins & After one hr & After six hrs & After twelve hrs & After twenty four hrs \\
Extract & Mean \pm std & Mean \pm std & Mean \pm std & Mean \pm std & Mean \pm std \\
Methanol leaf & $9.0 \pm 1.4 \mathrm{a}$ & $9.5 \pm 0.7 \mathrm{a}$ & $9.5 \pm 0.7 \mathrm{a}$ & $10.0 \pm 0.0 \mathrm{a}$ & $10.0 \pm 0.0 \mathrm{a}$ \\
Methanol stem & $8.5 \pm 2.1 \mathrm{a}$ & $9.0 \pm 1.4 \mathrm{a}$ & $10.0 \pm 0.0 \mathrm{a}$ & $10.0 \pm 0.0 \mathrm{a}$ & $10.0 \pm 0.0 \mathrm{a}$ \\
Hexane leaf & $8.0 \pm 1.4 \mathrm{a}$ & $9.0 \pm 1.4 \mathrm{a}$ & $9.5 \pm 0.7 \mathrm{a}$ & $10.0 \pm 0.0 \mathrm{a}$ & $10.0 \pm 0.0 \mathrm{a}$ \\
Hexane stem & $8.5 \pm 2.1 \mathrm{a}$ & $8.5 \pm 2.1 \mathrm{a}$ & $9.5 \pm 0.7 \mathrm{a}$ & $10.0 \pm 0.0 \mathrm{a}$ & $10.0 \pm 0.0 \mathrm{a}$ \\
Aqueous leaf & $7.5 \pm 0.7 \mathrm{a}$ & $8.5 \pm 0.7 \mathrm{a}$ & $9.5 \pm 0.7 \mathrm{a}$ & $10.0 \pm 0.0 \mathrm{a}$ & $10.0 \pm 0.0 \mathrm{a}$ \\
Aqueous stem & $6.5 \pm 0.7 \mathrm{a}$ & $8.0 \pm 1.4 \mathrm{a}$ & $9.0 \pm 1.4 \mathrm{a}$ & $9.5 \pm 0.7 \mathrm{a}$ & $10.0 \pm 0.0 \mathrm{a}$ \\
\hline
\end{tabular}

Supplementary Table 2. Mortalities of Anopheles gambiae larvae treated with $100 \mathrm{mg} / \mathrm{mL}$ of extracts.

\begin{tabular}{llllll}
\hline \multicolumn{7}{l}{ Mortality in time } & & $\mathbf{1 0 0} \mathbf{~ m g} / \mathbf{m l}$ \\
\hline Time & After 30 mins & After one hr & After six hrs & After twelve hrs & After twenty four hrs \\
Extract & Mean \pm std & Mean \pm std & Mean \pm std & Mean \pm std & Mean \pm std \\
Methanol leaf & $9.0 \pm 1.4 \mathrm{a}$ & $9.5 \pm 0.7 \mathrm{a}$ & $9.5 \pm 1.4 \mathrm{a}$ & $9.5 \pm 0.7 \mathrm{a}$ & $10.0 \pm 0.0 \mathrm{a}$ \\
Methanol stem & $7.5 \pm 0.7 \mathrm{a}$ & $8.5 \pm 0.7 \mathrm{a}$ & $9.0 \pm 0.0 \mathrm{a}$ & $10.0 \pm 0.0 \mathrm{a}$ & $10.0 \pm 0.0 \mathrm{a}$ \\
Hexane leaf & $7.5 \pm 2.1 \mathrm{a}$ & $8.0 \pm 1.4 \mathrm{a}$ & $9.5 \pm 0.7 \mathrm{a}$ & $9.5 \pm 0.7 \mathrm{a}$ & $10.0 \pm 0.0 \mathrm{a}$ \\
Hexane stem & $8.0 \pm 1.4 \mathrm{a}$ & $8.5 \pm 2.1 \mathrm{a}$ & $9.0 \pm 1.4 \mathrm{a}$ & $9.5 \pm 0.7 \mathrm{a}$ & $10.0 \pm 0.0 \mathrm{a}$ \\
Aqueous leaf & $6.0 \pm 1.4 \mathrm{a}$ & $8.0 \pm 1.4 \mathrm{a}$ & $9.0 \pm 1.4 \mathrm{a}$ & $9.0 \pm 1.4 \mathrm{a}$ & $10.0 \pm 0.0 \mathrm{a}$ \\
Aqueous stem & $6.0 \pm 0.0 \mathrm{a}$ & $7.0 \pm 1.4 \mathrm{a}$ & $8.5 \pm 0.7 \mathrm{a}$ & $9.0 \pm 1.4 \mathrm{a}$ & $10.0 \pm 0.0 \mathrm{a}$ \\
\hline
\end{tabular}

Supplementary Table 3. Mortalities of Anopheles gambiae larvae treated with $50 \mathrm{mg} / \mathrm{mL}$ of extracts.

\begin{tabular}{llllll}
\hline \multicolumn{7}{l}{ Mortality in time } & & & \\
\hline Time & After 30 mins & After one hr & After six hrs & After twelve hrs & After twenty four hrs \\
Extract & Mean \pm std & Mean \pm std & Mean \pm std & Mean \pm std & Mean \pm std \\
Methanol leaf & $8.0 \pm 1.4 \mathrm{a}$ & $9.0 \pm 1.4 \mathrm{a}$ & $8.5 \pm 2.1 \mathrm{a}$ & $9.5 \pm 0.7 \mathrm{a}$ & $10.0 \pm 0.0 \mathrm{a}$ \\
Methanol stem & $7.0 \pm 1.4 \mathrm{a}$ & $8.0 \pm 1.4 \mathrm{a}$ & $9.5 \pm 0.7 \mathrm{a}$ & $10.0 \pm 0.0 \mathrm{a}$ & $10.0 \pm 0.0 \mathrm{a}$ \\
Hexane leaf & $7.0 \pm 1.4 \mathrm{a}$ & $7.5 \pm 2.1 \mathrm{a}$ & $9.0 \pm 1.4 \mathrm{a}$ & $9.5 \pm 0.7 \mathrm{a}$ & $10.0 \pm 0.0 \mathrm{a}$ \\
Hexane stem & $6.0 \pm 1.4 \mathrm{a}$ & $7.5 \pm 2.1 \mathrm{a}$ & $9.0 \pm 1.4 \mathrm{a}$ & $9.0 \pm 1.4 \mathrm{a}$ & $10.0 \pm 0.0 \mathrm{a}$ \\
Aqueous leaf & $5.0 \pm 1.4 \mathrm{a}$ & $7.5 \pm 2.1 \mathrm{a}$ & $8.5 \pm 2.1 \mathrm{a}$ & $9.0 \pm 1.4 \mathrm{a}$ & $10.0 \pm 0.0 \mathrm{a}$ \\
Aqueous stem & $4.0 \pm 0.0 \mathrm{a}$ & $5.0 \pm 0.0 \mathrm{a}$ & $7.0 \pm 0.0 \mathrm{a}$ & $8.0 \pm 1.4 \mathrm{a}$ & $10.0 \pm 0.0 \mathrm{a}$ \\
\hline
\end{tabular}

Supplementary Table 4. Mortalities of Anopheles gambiae larvae treated with $25 \mathrm{mg} / \mathrm{mL}$ of extracts.

\begin{tabular}{llllll}
\hline \multicolumn{7}{l}{ Mortality in time } & & & \multicolumn{2}{c}{$\mathbf{2 5} \mathbf{~ m g} / \mathbf{m l}$} \\
\hline Time & After $30 \mathrm{mins}$ & After one hr & After six hrs & After twelve hrs & After twenty four hrs \\
Methact & Mean \pm std & Mean \pm std & Mean \pm std & Mean \pm std & Mean \pm std \\
Methanol stem & $7.5 \pm 2.1 \mathrm{a}$ & $8.5 \pm 2.1 \mathrm{a}$ & $9.0 \pm 1.4 \mathrm{a}$ & $9.0 \pm 1.4 \mathrm{a}$ & $10.0 \pm 0.0 \mathrm{a}$ \\
Hexane leaf & $6.5 \pm 2.1 \mathrm{a}$ & $7.5 \pm 0.7 \mathrm{a}$ & $9.0 \pm 0.0 \mathrm{a}$ & $9.5 \pm 0.7 \mathrm{a}$ & $10.0 \pm 0.0 \mathrm{a}$ \\
Hexane stem & $6.0 \pm 1.4 \mathrm{a}$ & $6.5 \pm 2.1 \mathrm{a}$ & $7.5 \pm 2.1 \mathrm{a}$ & $9.0 \pm 1.4 \mathrm{a}$ & $10.0 \pm 0.0 \mathrm{a}$ \\
Aqueous leaf & $4.0 \pm 1.4 \mathrm{a}$ & $6.0 \pm 2.8 \mathrm{a}$ & $7.5 \pm 2.1 \mathrm{a}$ & $8.5 \pm 2.1 \mathrm{a}$ & $10.0 \pm 0.0 \mathrm{a}$ \\
Aqueous stem & $3.5 \pm 2.1 \mathrm{a}$ & $5.0 \pm 2.8 \mathrm{a}$ & $6.5 \pm 2.1 \mathrm{a}$ & $7.5 \pm 0.7 \mathrm{a}$ & $10.0 \pm 0.0$ \\
\hline
\end{tabular}

Supplementary Table 5. Mortalities of Anopheles gambiae larvae treated with control.

P. C. Ayogu and C. C. Ugwu (2019) / Phytochemical analysis and larvicidal potentials of Jatropha curcas L. leaf and stem extracts against Anopheles gambiae 
Int. J. Curr. Res. Biosci. Plant Biol. (2019) 6(2), 48-60

\begin{tabular}{|c|c|c|c|c|c|c|c|c|c|c|}
\hline \multicolumn{8}{|c|}{ Mortality in time } & \multicolumn{3}{|c|}{ Control mg/ml } \\
\hline Time & \multicolumn{2}{|c|}{ After 30 mins } & \multicolumn{2}{|c|}{ After one hr } & After six hrs & \multicolumn{2}{|c|}{ After twelve hrs } & \multicolumn{3}{|c|}{ After twenty four hrs } \\
\hline Extract & \multicolumn{2}{|c|}{ Mean \pm std } & \multicolumn{2}{|c|}{ Mean \pm std } & Mean \pm std & \multicolumn{2}{|c|}{ Mean \pm std } & \multicolumn{2}{|c|}{ Mean \pm std } & \\
\hline Methanol leaf & \multicolumn{2}{|c|}{ NA } & \multicolumn{2}{|c|}{ NA } & NA & \multicolumn{2}{|c|}{ NA } & \multicolumn{3}{|c|}{ NA } \\
\hline Methanol stem & \multicolumn{2}{|l|}{ NA } & \multicolumn{2}{|l|}{ NA } & NA & \multicolumn{2}{|l|}{ NA } & \multicolumn{3}{|c|}{ NA } \\
\hline Hexane leaf & NA & & NA & & & NA & & NA & & \\
\hline Hexane stem & NA & & NA & & & NA & & NA & & \\
\hline Aqueous leaf & NA & & NA & & & NA & & $\mathrm{NA}$ & & \\
\hline Aqueous stem & NA & & NA & & & NA & & $\mathrm{NA}$ & & \\
\hline & & & & ummarize & Result of $t$ & he Analysi & & & & \\
\hline Methan.leaf.ext & $\begin{array}{c}\text { Mean } \\
\text { mortalit } \\
y \\
\text { after } 30 \\
\text { mins }\end{array}$ & 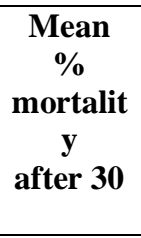 & $\begin{array}{c}\text { Mean } \\
\text { mortalit } \\
y \\
\text { after } 60 \\
\text { mins }\end{array}$ & $\begin{array}{c}\text { Mean \% } \\
\text { mortalit } \\
y \\
\text { after } 60 \\
\text { mins }\end{array}$ & $\begin{array}{c}\text { Mean } \\
\text { mortalit } \\
y \\
\text { after } 6 \\
\text { hrs }\end{array}$ & $\begin{array}{c}\text { Mean } \\
\% \\
\text { mortalit } \\
y \\
\text { after } 6 \\
\text { hrs } \\
\end{array}$ & $\begin{array}{c}\text { Mean } \\
\text { mortalit } \\
y \\
\text { after } 12 \\
\text { hrs }\end{array}$ & $\begin{array}{c}\text { Mean } \\
\% \\
\text { mortalit } \\
\mathbf{y} \\
\text { after } 12 \\
\text { hrs } \\
\end{array}$ & $\begin{array}{c}\text { Mean } \\
\text { mortalit } \\
y \\
\text { after } 24 \\
\text { hrs }\end{array}$ & $\begin{array}{c}\text { Mean } \\
\% \\
\text { mortalit } \\
\mathbf{y} \\
\text { after } \\
24 \mathrm{hrs} \\
\end{array}$ \\
\hline $200 \mathrm{mg} / \mathrm{ml}$ & 9.0 & 90 & 9.5 & 95 & 9.5 & 95 & 10.0 & 100 & 10.0 & 100 \\
\hline $100 \mathrm{mg} / \mathrm{ml}$ & 9.0 & 90 & 9.5 & 95 & 9.0 & 90 & 9.5 & 95 & 10.0 & 100 \\
\hline $50 \mathrm{mg} / \mathrm{ml}$ & 8.0 & 80 & 9.0 & 90 & 8.5 & 85 & 9.5 & 95 & 10.0 & 100 \\
\hline $25 \mathrm{mg} / \mathrm{ml}$ & 7.5 & 75 & 8.5 & 85 & 9.0 & 90 & 9.0 & 90 & 10.0 & 100 \\
\hline Control & 0.0 & 0 & 0.0 & 0 & 0.0 & 0 & 0.0 & 0 & 0.0 & 0 \\
\hline $\begin{array}{l}\text { Methanol.stem. } \\
\text { ext }\end{array}$ & & & & & & & & & & \\
\hline $200 \mathrm{mg} / \mathrm{ml}$ & 8.5 & 85 & 9.0 & 90 & 10.0 & 100 & 10.0 & 100 & 10.0 & 100 \\
\hline $100 \mathrm{mg} / \mathrm{ml}$ & 7.5 & 75 & 8.5 & 85 & 9.00 & 90 & 10.0 & 100 & 10.0 & 100 \\
\hline $50 \mathrm{mg} / \mathrm{ml}$ & 7.0 & 70 & 8.0 & 80 & 9.5 & 95 & 10.0 & 100 & 10.0 & 100 \\
\hline $25 \mathrm{mg} / \mathrm{ml}$ & 6.0 & 60 & 7.5 & 75 & 9.0 & 90 & 9.5 & 95 & 10.0 & 100 \\
\hline Control & 0.0 & 0 & 0.0 & 0 & 0.0 & 0 & 0.0 & 0 & 0.0 & 0 \\
\hline Hexane-leaf & & & & & & & & & & \\
\hline $200 \mathrm{mg} / \mathrm{ml}$ & 8.0 & 80 & 9.0 & 90 & 9.5 & 95 & 10.0 & 100 & 10.0 & 100 \\
\hline $100 \mathrm{mg} / \mathrm{ml}$ & 7.5 & 75 & 8.0 & 80 & 9.5 & 95 & 9.5 & 95 & 10.0 & 100 \\
\hline $50 \mathrm{mg} / \mathrm{ml}$ & 7.0 & 70 & 7.5 & 75 & 9.0 & 90 & 9.5 & 95 & 10.0 & 100 \\
\hline $25 \mathrm{mg} / \mathrm{ml}$ & 6.5 & 65 & 7.0 & 70 & 8.5 & 85 & 8.5 & 85 & 10.0 & 100 \\
\hline Control & 0.0 & 0 & 0.0 & 0 & 0.0 & 0 & 0.0 & 0 & 0.0 & 0 \\
\hline Hexane-stem & & & & & & & & & & \\
\hline $200 \mathrm{mg} / \mathrm{ml}$ & 8.5 & 85 & 8.5 & 85 & 9.5 & 95 & 10.0 & 100 & 10.0 & 100 \\
\hline $100 \mathrm{mg} / \mathrm{ml}$ & 8.0 & 80 & 8.5 & 85 & 9.0 & 90 & 9.5 & 95 & 10.0 & 100 \\
\hline $50 \mathrm{mg} / \mathrm{ml}$ & 6.0 & 60 & 7.5 & 75 & 9.0 & 90 & 9.0 & 90 & 10.0 & 100 \\
\hline $25 \mathrm{mg} / \mathrm{ml}$ & 6.0 & 60 & 6.5 & 65 & 7.5 & 75 & 9.0 & 90 & 10.0 & 100 \\
\hline Control & 0.0 & 0 & 0.0 & 0 & 0.0 & 0 & 0.0 & 0 & 0.0 & 0 \\
\hline Aqueous-leaf & & & & & & & & & & \\
\hline $200 \mathrm{mg} / \mathrm{ml}$ & 7.5 & 75 & 8.5 & 85 & 9.5 & 95 & 10.0 & 100 & 10.0 & 100 \\
\hline $100 \mathrm{mg} / \mathrm{ml}$ & 6.0 & 60 & 8.0 & 80 & 9.0 & 90 & 9.0 & 90 & 10.0 & 100 \\
\hline $50 \mathrm{mg} / \mathrm{ml}$ & 5.0 & 50 & 7.5 & 75 & 8.5 & 85 & 9.0 & 90 & 10.0 & 100 \\
\hline $25 \mathrm{mg} / \mathrm{ml}$ & 4.0 & 40 & 6.0 & 60 & 7.5 & 75 & 8.5 & 85 & 10.0 & 100 \\
\hline Control & 0.0 & 0 & 0.0 & 0 & 0.0 & 0 & 0.0 & 0 & 0.0 & 0 \\
\hline Aqueous-stem & & & & & & & & & & \\
\hline $200 \mathrm{mg} / \mathrm{ml}$ & 6.5 & 65 & 8.0 & 80 & 9.0 & 90 & 9.5 & 95 & 10.0 & 100 \\
\hline $100 \mathrm{mg} / \mathrm{ml}$ & 6.0 & 60 & 7.0 & 70 & 8.5 & 85 & 9.0 & 90 & 10.0 & 100 \\
\hline
\end{tabular}

P. C. Ayogu and C. C. Ugwu (2019) / Phytochemical analysis and larvicidal potentials of Jatropha curcas L. leaf and stem 